Voix et Images

voixetimages

\title{
Quarantième anniversaire : rétrospective
}

\section{Luc Bonenfant}

Volume 40, numéro 3 (120), printemps-été 2015

URI : https://id.erudit.org/iderudit/1032642ar

DOI : https://doi.org/10.7202/1032642ar

Aller au sommaire du numéro

Éditeur(s)

Université du Québec à Montréal

\section{ISSN}

0318-9201 (imprimé)

1705-933X (numérique)

Découvrir la revue

Citer ce document

Bonenfant, L. (2015). Quarantième anniversaire : rétrospective. Voix et Images, 40(3), 155-155. https://doi.org/10.7202/1032642ar d'utilisation que vous pouvez consulter en ligne.

https://apropos.erudit.org/fr/usagers/politique-dutilisation/ 


\title{
QUARANTIÈME ANNIVERSAIRE : RÉTROSPECTIVE
}

\author{
$+++$ \\ LUC BONENFANT \\ Université du Québec à Montréal
}

L'histoire de Voix et Images reste intimement liée à celle de l'Université du Québec à Montréal. Les Cahiers Sainte-Marie (du nom du collège qui est à l'origine de la fondation de notre université) accueillaient en effet le tout premier numéro de la revue, alors appelée Voix et Images du pays, en avril 1967. Un second numéro de Voix et Images du pays sera publié dans les Cahiers Sainte-Marie en 1969, avant que la revue ne paraisse aux Presses de l'Université du Québec.

C'est à cette histoire que nous souhaitons maintenant rendre hommage pour clore la rétrospective dédiée aux quarante ans de la revue, en republiant un texte de Jacques Pelletier initialement paru en 1970 dans Voix et Images du pays: «André Major, écrivain et Québécois». 